\title{
38. DATA REPORT: PALEOMAGNETIC MEASUREMENTS OF PALEOCENE-EOCENE SEDIMENTS, LEG 143, HOLES 865B AND 865C ${ }^{1}$
}

\author{
Evelyn L. Polgreen ${ }^{2}$ and William W. Sager ${ }^{2}$
}

\section{INTRODUCTION}

At Allison Guyot, during Ocean Drilling Program (ODP) Leg 143, Paleocene-Eocene pelagic nannofossil foraminiferal oozes and sands were cored in Holes $865 \mathrm{~B}$ and $865 \mathrm{C}$. The section was double-APCcored using the advanced hydraulic piston corer (APC) because of both the rarity of a section of this age in the Pacific Ocean and its potential importance for paleoceanographic study. Drilling at Hole 865B penetrated $165.5 \mathrm{mbsf}$, including five extended core barrel (XCB) cores at the base, while Hole $865 \mathrm{C}$ was drilled to $136.3 \mathrm{mbsf}$ (Sager, Winterer, Firth, et al., 1993).

Whole-core measurements taken aboard ship were rendered useless because rust from the drill string was smeared along the edges of the cores by the drilling process (Sager, Winterer, Firth, et al., 1993). Also, the discrete samples of the sediments were too weakly magnetic to be measured accurately using the shipboard cryogenic magnetometer. Consequently, we initiated a shore-based study to measure the magnetic polarity stratigraphy of this section.

\section{METHODS}

A total of 65 samples was taken from Hole $865 \mathrm{~B}$ cores and 74 samples from Hole $865 \mathrm{C}$ cores, with one sample taken per section (unless the section was highly disturbed). Many cores were disturbed, typically in the uppermost sections. For example, the first few sections of the three cores at the top of Holes $865 \mathrm{~B}$ and $865 \mathrm{C}$ were so watery that the sediment seemed to flow within the liner. Samples were taken from the less disturbed core sections using $6-\mathrm{cm}^{3}$ plastic cubes. Samples were refrigerated and measured promptly to guard against drying effects.

Magnetic remanence was measured using a CTF cryogenic magnetometer in the Geophysics Department of Texas A\&M University. After the natural remanent magnetization (NRM) was measured, samples were demagnetized stepwise, using an alternating magnetic field (AF). Twelve pilot samples from Hole $865 \mathrm{~B}$ were demagnetized in fields of up to $100 \mathrm{mT}$. To check the consistency of the magnetic behavior from sample to sample, an isothermal remanent magnetization (IRM) was imparted to each of the pilot samples using an impulse magnetizer in which capacitors release a surge of current through a

\footnotetext{
' Winterer, E.L., Sager, W.W., Firth, J.V., and Sinton, J.M. (Eds.), 1995, Proc, ODP. Sci. Results, 143: College Station, TX (Ocean Drilling Program).

2
3146 , U.S. A.
}

coil to produce a field of up to $1200 \mathrm{mT}$ for about $2 \mathrm{~ms}$. Using this device, pilot samples were magnetized in progressively higher fields until saturation occurred. The remaining samples from both holes were demagnetized in fields of up to $50 \mathrm{mT}$, past their mean destructive field (MDF).

We plotted all demagnetization steps on orthogonal vector (Zijderveld) plots to examine the directional behavior of the samples during demagnetization. Characteristic remanent magnetization vectors were determined by fitting a least-squares line to measurements to show univectorial decay. We averaged magnetic cleaning steps using the least-squares method (Kirschvink, 1980). Sample declinations were corrected using magnetic orientations obtained from multishot camera data. Inclinations, declinations, and corrected declinations were plotted vs. depth (Fig. 1).

\section{RESULTS}

Magnetic intensities were weak $\left(10^{-11} \mathrm{Am}^{2}-10^{-9} \mathrm{Am}^{2}\right)$. Uncorrected declinations showed consistent values between about $+90^{\circ}$ and $-90^{\circ}$ (Fig. 1), rather than changing at core breaks, as expected for unoriented cores. Moreover, inclinations should have been near $0^{\circ}$ for this low latitude site, but many samples gave values in excess of $+20^{\circ}$ or $-20^{\circ}$.

Although samples typically displayed demagnetization behavior that suggested a stable, characteristic remanence was isolated, the consistency in uncorrected declinations and inconsistency in inclinations implied that the cores had been remagnetized during drilling or handling. We postulate that the fluid conditions of these cores was an important factor in making the cores useless for paleomagnetic studies.

\section{REFERENCES ${ }^{*}$}

Kirschvink, J.L., 1980. The least-squares line and plane and analysis of palaeomagnetic data. Geophys. J. R. Astron. Soc., 62:699-718.

Sager, W.W., Winterer, E.L., Firth, J.V., et al., 1993. Proc. ODP, Init. Repts., 143: College Station, TX (Ocean Drilling Program).

\footnotetext{
"Abbreviations for names of organizations and publications in ODP reference lists follow the style given in Chemical Abstracts Service Source Index (published by American Chemical Society).
}

Date of initial receipt: 1 December 1993

Date of acceptance: 28 June 1994

Ms 143SR-234 

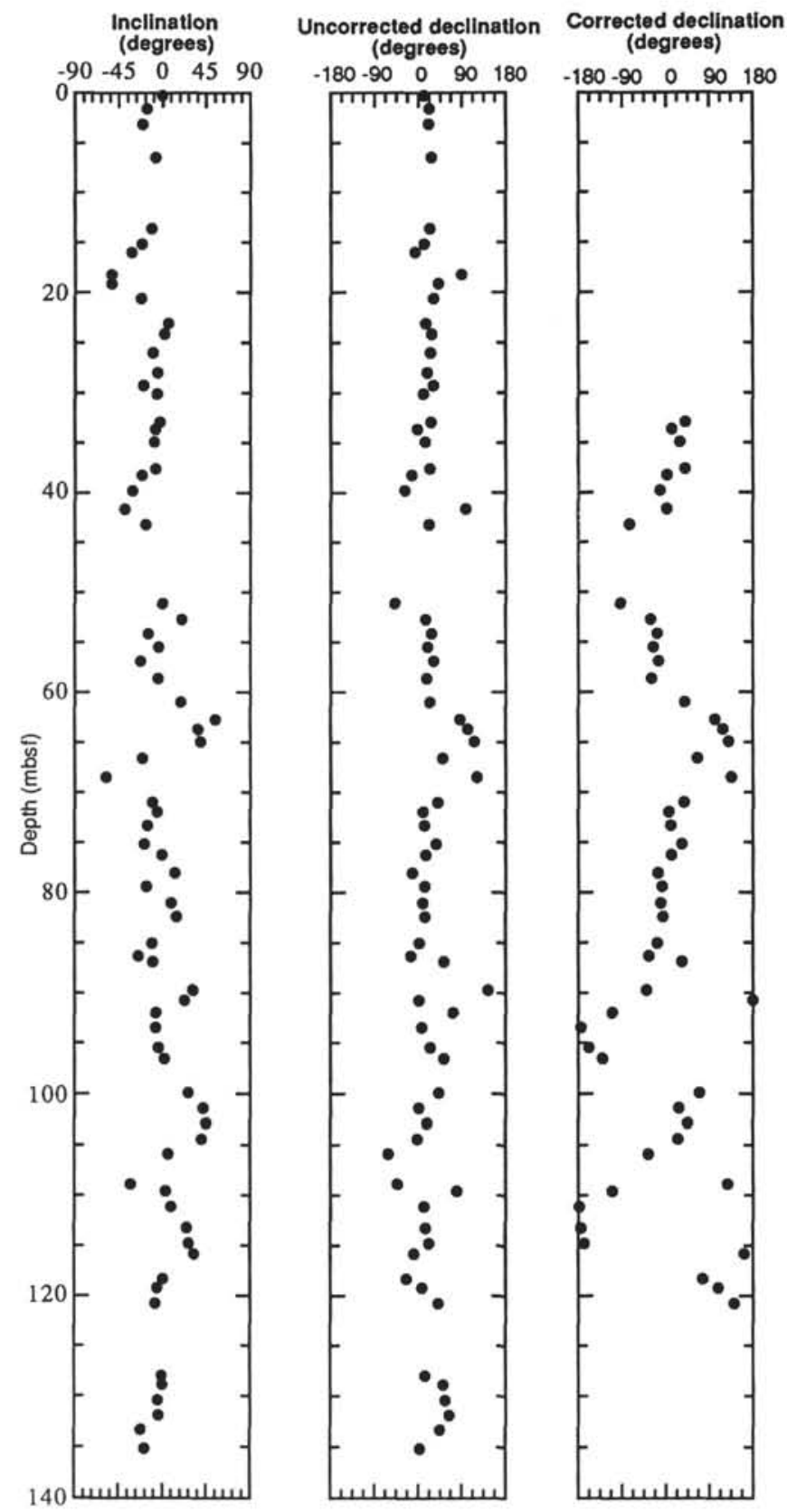

Figure 1. Inclination, declination, and corrected declination plotted vs. depth for Hole $865 \mathrm{C}$. 